\title{
Model of valorization of soils under viewpoint of their potential resistance against some selected contaminants (based on the author's PhD thesis)
}

\begin{abstract}
Preliminary assumptions
Under the soil degradation notion we understand both mechanical devastation of soils and the results of this devastation. While analyzing the effect of contamination on agricultural lands mostly $\mathrm{SO}_{2}$ and dust fall are taken into consideration. In the first case a threat measure was variable soil reaction, in the second - the quantitative dust fall per area unit. On the other hand. the qualitative composition of dust and its actual effect on soil and plants were taken into consideration to the minimum degree, whereas the mutual relations between particular contaminants one the given area was totally disregarded. The main threat for soil and plants constitute heavy metals. Their effect on the environment was underestimated for a rather long time. This was connected with a weak negative reaction of plants and the more of soil to their accumulation. Only the animal and human organism appeared to be a faultless bioindicator of their occurrence. Preliminary determination of admissible maximum values of occurrence of heavy metals in the human organism caused a start of investigations aiming at determination of admissible values of these metals in the human organism caused a start of investigations came towards full recognition of heavy metals occurrence ways in soil and plants, determination of tolerance level and threshold values for particular elements and their groups. If the result of verification based upon the above criteria was positive for the agricultural lands investigated, the crop production process should not undergo any limitations. If, on the other hand. the result was negative, to categories of soils should be distinguished. viz. these which should be absolutely excluded from plant production on which should be run in a controlled way adapted to the increased soil contamination level. Separation of both groups constitutes
\end{abstract}

\footnotetext{
Instytut Ekologii i Bioetyki UKSW w Warszawie.
} 
the first step towards minimization of the plant production contamination. The process of separation of this type of soil groups based on the soil contamination state constitutes the first step towards determination of the role of soil in contamination of the plant products. On the other hand, determination of the potential resistance of soil to contamination constitutes the final work stage. Realization of this resistance should take into consideration possibly widest actual state of the environment contamination as well as main soil parameters and possibly also other selected factors of the environment. The determination of mutual relations between the above factors would allow to construct a model, which would objectively characterize the actual state of soil resistance to contamination. The model should at the same time constitute a basis for plant production planning on areas with increased threat, particularly in the regions of large urban agglomerations.

The realization of such a model taking into consideration both soil parameters and degrading factors, requires working out valuation methods. In my work I presented selected problems concerning natural valuation of their development from trends of agricultural valuation of the productive area through their valuation at consideration of the processes of progressing degradation of soils due to the contamination of the environment to alternative techniques estimating the effect of contamination's on soil jointly with the computer technique. Difficulties met beginning from the natural valuation of productive soils are rather remarkable also for later stages taking into consideration degrading elements and leading to construction of synthetic models.

According to Witek (1985) "difficulties in an appropriate complex approach to environmenta1 data including soil parameters, are connected, among other things, with a lack of answer to the question, which among traits and properties of soil would affect significantly the yielding of plants. The following natural properties and traits of soil are responsible for their value and agricultural suability of soil: granulometric composition and its variability in the profile, water conditions, reaction and culture degree".

Consideration of only natural traits and their more or less successive taxation become unsatisfactory when degraded areas are concerned. Therefore, also areas around large urban or industrial agglomeration require, first off all, working out a system of actions based upon a correct estimation of the occurrence level of contaminants on the given area and their effect on soil as well as upon estimation of potential threat for plant production on the part of the environment contaminants.

In any valuation of agricultural areas a principal role is played by the registration of basic contaminants. It can occur in manifold ways. There is no guideline up to now giving the answer to the question what elements 
should be taken into consideration and what could be omitted. Specialists are guide usually by the aim of the given work. An additiona1 difficulty is lack of developed unequivocal indices of admissible occurrence level of these elements both in soil and plants, determination of accumulation ways of the contaminants in consequence of soil and air pollution. A significant problem is that contaminants do not occur singly; they form most often characteristic systems e.g. for urban agglomerations $\mathrm{Pb}, \mathrm{Cd}, \mathrm{B}, \mathrm{Zn}$ and $\mathrm{SO}_{2}$. Therefore, they cannot be considered separately. Interpretation of estimation of the effect of contaminants on soil is thus not possible with the use of traditional methods. Only making use of computer techniques offers new possibilities, creating, on the other hand, some other difficulties. Some of them consist in:

- A lack of unified analytical methods: as long as this state not improves we would be compelled to limit consciously the set of data and to make choice far from optimum one. This is connected with the question of comparability of data and consequently with the scale of works: data of different scales can be comparable from technical viewpoint, still their use would negatively affect the exactness of results,

- input registration of materials in the form of maps (digimetres in the computer method),

- Interpretation way of the registered material (any error would cause a change reaction),

- Necessity of presentation of all data in the form of superficial record.

A basis of the use of computer techniques is developing an algorithm which would include all the data introduced in the first part of the work. In this case, beside an appropriate connection of input the problem arises of valuation of different parameters, both individually and for the whole system, they are so-called weight coefficients. Disregarding of such coefficients will cause that, after mobilization of the functions, interpretation of the results would appear to be erroneous. Assumption of constant weight coefficients of this type would decide about legibility of the analysis performed by computer and about, of course, of correctness of the results obtained. Eight basic elements have been used in the present work for determination of the weight coefficient. However, no concrete values of the weight coefficient, only definite ranks of the elements considered were determined as a result of the above. The selection of numerical values has been done just on the basis of the ranks as mentioned above. The structure of algorithm is connected, first of all, with the reaction between parameters being in close correlation with the elements investigated. Taking into consideration these connections and their supplementation with weight coefficients constitute a basis of solution of the first part of the algorithm. 


\section{Material areas and methods of investigations}

The collected material consists of both results of own investigations and data from various works. A basic map, i.e. map of the area utilization, was worked out. It was determination of agricultural lands and exclusion a priori from the agricultural production of the areas adjoining the traffic routes.

The subsequent soil maps and maps of the granulometric composition were worked out on the basis of the map of soil complexes and the map of soils worked out by the Laboratory of Physiography for the city of Warsaw. Basing on the above data, I plotted the map of soils and the map of granulometric composition already considerably changed and generalized.

This work allowed to obtain a map consisting of 8 basic elements. Then I worked out a map of shallow ground waters. Three zones: Vistula valley, moraine upland, freshly urbanized area, have been marked on the map. Ground water tables for these zones were determined. The next map concerns the $\mathrm{pH}$ value of soil. Also investigations on the contamination degree with $\mathrm{Pb}$ and $\mathrm{Cd}$ were carried out. These investigations allowed to separate the area, which could be subjected to the algorithmic analysis.

The area under study constitutes a part of the mezoregion of midd1e Vistula sector and of Warsaw plain. To this mezoregion the flooded terrace and higher sandy dune terrace are assigned. The width of the so conceived valley ranges within the limits of $10 \mathrm{~km}$. The area analyzed lies in the northern part of this mezoregion. The area situated in a part of the mezoregion of middle Vistulas sector eastwards the road connecting the Wilanów and Konstancin. Localities is built of slightly silty loamy sand, typical silt, light loamy sand, light silty loam and medium silty loam. Rather considerable areas are occupied by degraded black earth's developed from light loamy sand, heavy silty loamy sand and heavy loamy sand. On the areas comprised with the algorithmic analysis occur typical brown soils, black earth's and alluvial muck soils on peat.

On the soils investigated $\mathrm{pH}$ values over 6.6 and 5.6-6.5 prevailed. Only $5 \%$ of the soils showed the $\mathrm{pH}$ values of $4.6-5.5$. On soils subjected to the algorithmic ana1ysis areas with the ground water table or $1.1-2.5 \mathrm{~m}$ and $0.0-1.0 \mathrm{~m}$ prevail.

A basis for separation of the areas to be analyzed was determination of the actual state of soil contamination. On the basis of my considerations presented in the chapter. I assumed as a basic index the content of lead and cadmium in soil. The sampling places were established according to the area relief. To perform an appropriate interpretation of the above data and to determine the investigation area, I used the following table constructed by myself: 
Model of valorization of soils under viezupoint of their potential resistance against...

\begin{tabular}{|c|c|c|c|}
\hline Element & $\begin{array}{c}\text { Contamination values of } \\
\text { soil on which the } \\
\text { agricultural production can } \\
\text { be run unlimited }\end{array}$ & $\begin{array}{c}\text { Contamination values of } \\
\text { soil on which the } \\
\text { agricultural production } \\
\text { can be run on condition of } \\
\text { considering potential } \\
\text { resistance of soil against } \\
\text { contamination }\end{array}$ & $\begin{array}{c}\text { Contamination values of } \\
\text { soil on which agricultural } \\
\text { production cannot be run } \\
\text { irrespective of the potential } \\
\text { resistance of soil against } \\
\text { contamination and of crop } \\
\text { kind; only decorative } \\
\text { plants can be cultivated }\end{array}$ \\
\hline $\mathbf{P b}$ & Up to $40 \mathrm{ppm}$ & II & III \\
\hline $\mathbf{C d}$ & Up to $1 \mathrm{ppm}$ & $40-100 \mathrm{ppm}$ & Over 100ppm \\
\hline
\end{tabular}

Basing on the above data, I have determined the area for exact investigations through mobilization within its limits of the algorithm, the task of which was to present potential resistance of soils against 6 selected contaminants.

The registration of the source material on magnetic tapes was carried out with the use of Codimat. Main essential problems that were to be solved here were: size of the area registered, machine memory and problem of size of basic fields (consequently a map based upon the mosaic of signs bas been obtained). One sign on the map means a definite place on the area (square of $200 \mathrm{~m}$. side).

The next step was the choice of appropriate parameters and their presentation in the numerical form. Considerations concerning the choice of parameters and their reaction with concrete elements are presented in one the chapter of my work.

The above considerations allowed me to determine the basic 1st degree links for the algorithm. In such a way I obtained XI links constituting a basis for the algorithm construction.

\begin{tabular}{|l|l|l|l|}
\hline $\mathrm{I}$ & & & \\
\hline $\begin{array}{l}\text { Granulometric composition- } \mathrm{Pb}, \mathrm{Cd}, \mathrm{B} \\
\mathrm{pH}-\mathrm{SO}_{2}\end{array}$ & $\begin{array}{l}\text { III } \\
\mathrm{pH}-\mathrm{Pb}\end{array}$ & $\begin{array}{l}\mathrm{IV} \\
\mathrm{pH}-\mathrm{Cd}\end{array}$ & $\begin{array}{l}\mathbf{V} \\
\mathrm{pH}-\mathrm{Zn}\end{array}$ \\
\hline $\mathrm{VI}$ & $\begin{array}{l}\text { VII } \\
\text { Moisture- } \mathrm{SO}_{2}\end{array}$ & & \\
Moisture-Cd & $\mathbf{I X}$ & $\mathbf{X}$ & \\
\hline $\begin{array}{l}\text { VIII } \\
\text { Organic matter-Cd }\end{array}$ & Organic matter-Pb & Organic matter-Cu & \\
\hline $\begin{array}{l}\mathrm{XI} \\
\text { Ogganic matter-Cd, } \mathrm{Pb}, \mathrm{Cu}\end{array}$ & & \\
\hline
\end{tabular}

The subsequent action was introduction of the above links into concrete basic fields of the area investigated. This operation enabled to get initial data for algorithmic calculations. These data are presented in the 10 schemes enclosed to the work. To facilitate the reading and its analysis, all sectors and maps were divided into 4 classes forming the so- 
called threat intervals. The analysis of the above material proves that the most part of the area in question is in the composition of the first and second threat interval. Beside 1st-degree links introduced into the algorithm according to the above schemes, a significant role in constructing the algorithm played the 2nd-degree links. Basic links of the 2nd degree were formed due to the necessity of supplementation of an appropriate functioning of 5 1st-degree links: the second, third, fifth, sixth, eight. Basic links of the 2nd degree are links formed from the 1stdegree links, but limited in their functioning by same circumstances.

$$
\begin{aligned}
& I I-I+X \\
& I I I-I A+X I I A \\
& V-I B+X I C \\
& V I-X I I B \\
& V I I I-I C \\
& \text { WSP - coefficient }
\end{aligned}
$$

The IA and XIIA links constitute suplementation at solution of the third link. This makes that the number assumed for the relationship between $\mathrm{pH}$ and $\mathrm{Pb}$ are additionally conditioned with the fact that at the moment of overlapping the parameter of granulometric composition and $\mathrm{pH}$ over this factor their role increases when actual level of the granulometric composition on the area in question is determined below 6 points. This means in the practice that the whole number of points concerning granulometric composition over the whole area is lower than 6. Therefore, in this whole link $\mathrm{pH}$ value increases by two units. Just this role is played by the basic 2nd-degree link XIIA. Consequently this is number of points for $\mathrm{pH}$ increased by two units.

Similarly is in case of the link V of the 1st degree. The IB link means that at the moment when the number of points for the granulometric composition is 4 and 5, two fold increase of the threat on the part of $\mathrm{Zn}$ accumulation occurs. On the other hand, when $\mathrm{pH}$ value is higher than 6.5 , this phenomenon ceases to exist. The first relationship was recorded in the form of IB and the second in that of XIIC. In other words, at the moment of higher $\mathrm{pH}$ value for the XIIC link than 6.5, the area of basic field would obtain zero points.

The role of the XIIB link tan be explained in such a war that at the moment of registration of data for the basic link of the degree VI and at the same time the $\mathrm{pH}$ value of over 6.8 occurs, the number of points assumed in consequence of the moistening role ceases to have any importance, as the phenomenon under the above natural conditions is not registered.

At last the realization of the link VIII is possible by introduction of condition in the form of the 2 nd-degree link IC. This proves that there is 
a correlation between the cadmium accumulation and granulometric composition. This phenomenon is functioning only when the number of points by which the granulometric composition is marked, is below 5 . This phenomenon occurs over the whole area in question and in this connection the IC link is disregarded, while the link VIII remains unchanged in its points. In such a way all assumptions of the chapters 3.5.-3.6 have been recorded numerically and occur in the form of basic links of the first and second degree. They constitute a basis of the algorithm contraction. Among the supplementing links of the 2 nd degree for the algorithm a very important role play weight coefficients. In constructing the essential bases for determination of these coefficients I was guided with the role played by selected contaminants. I tried to determine the role played by these contaminants in the relation to the parameters under study. In this case I took into consideration such parameters, as granulometric composition, $\mathrm{pH}$ values, moisture level and organic matter content at $\mathrm{pH}$ below and above 7 . The subsequent problem considered at determination of the weight coefficient was the bioaccumulation level of particular contaminants in the plant. The last third group constituted considerations on the subject of number of synergistic and antagonistic relations for soil and plants. In the final specification the elements in question could be ordered with regard to the environment threat in the following sequence:

$$
\mathrm{Cd}>\mathrm{Pb}>\mathrm{SO} 2>\mathrm{B}>\mathrm{Zn}>\mathrm{Cu}
$$

Just on this basis I have determined the final weight coefficients, which were introduced before links for particular elements.

\section{Construction of the algorithm and discussion of results}

Crowning of all these actions is constructed algorithm consisting of two parts. In the left part individual series of the 1 st and 2 nd-degree links for the elements under consideration are to be found. Arrows in this part indicate connections existing here at the level of parameters. Therefore, I named this part of the algorithm "Relation based on effects upon definite parameters. The right part of the algorithm presents connections taken into consideration as "Relation based upon synergistic and antagonistic systems". The lines between particular links mean the connection force of value of $0.5-1.0$. The OK symbol means result.

$$
\begin{aligned}
& \mathrm{Pb}-\mathrm{I}+\mathrm{III}[\mathrm{IA}+\mathrm{XIIA}]+\mathrm{IX}-\mathrm{OP} \\
& \mathrm{SO}_{2}-[\mathrm{II}+\mathrm{VII}]-\mathrm{OS}
\end{aligned}
$$




$$
\begin{aligned}
& \mathrm{Cd}-\mathrm{I}+\mathrm{IV}+\mathrm{VI}[\mathrm{XIIB}]+\mathrm{VIII}-\mathrm{OC} \\
& \mathrm{Zn}-\mathrm{V}[\mathrm{IB}+\mathrm{XIIC}]-\mathrm{OZ} \\
& \mathrm{Cu}-\mathrm{X}-\mathrm{OU} \\
& \text { B - I - OB }
\end{aligned}
$$

The algorithm construction comprises 6 basic contaminants and soil differentiation through soil parameters as well as the other selected environment elements conceived in the numerical form in the phase of construction of soil parameters. The algorithm constructed in such a way is a certain model, the basic task of which is determination of mutual relationships between the groups of factors as mentioned above, allowing the objective maximum determination of the actual state of soil resistance against contamination. Mobilization of this algorithm allows to get same groups of numbers for definite basic fields. Upon performing verification of the scale and determining intervals of threat. I have got a map of potential resistance of soils against 6 selected contaminants. In consequence of the final analysis of data the whole area has been assigned to one class of threat. The obtained numerical values for particular basic fields showed I rather considerable fluctuations, still after getting the map the whole area has been assigned to the first class of resistance.

The results obtained in such a way prove that the area subjected to the algorithmic analysis is completely safe for any plant production kind. No limitations in the structure of crops are provided. The threat for crops on the part of soil is minimal and lies in the first interval of the four-degree scale of threat. At a growth of contaminants, which is observed up to now over the area in question, a fully safe plant production in the at least 10-year period can be run. At the moment of growth of the soil contamination to the upper threshold values for the 2nd class of soil contamination with lead and cadmium, the soil of the area will show a high resistance due to the fact that it belongs to the first class of the potential soil resistance against contaminants.

Parameters connected with soil only have been taken into consideration in the present work. Therefore the answer to the question put at the beginning can be done only on the basis of threat on the part of soil and at that only in limitation to 6 selected contaminants. A full answer could be obtained only after supplementation of the present investigations with models solving the problem of the contamination effect on edible plants on the part of air. In construction of models of such a type other factors, such as accumulation places of definite contaminants in plants, possibility of translocation of contaminants of plant from roots to aboveground parts and vice versa. I presume that realization of these problems and formation of unequivocal estimation 
bases would enable to construct general models of threat, in which all the above threat factors and trends will be represented at consideration of effects of various contaminants. The solution of this problem will allow to introduce in unequivocal way of planning the structure of crops adapted to the areas with increased threat.

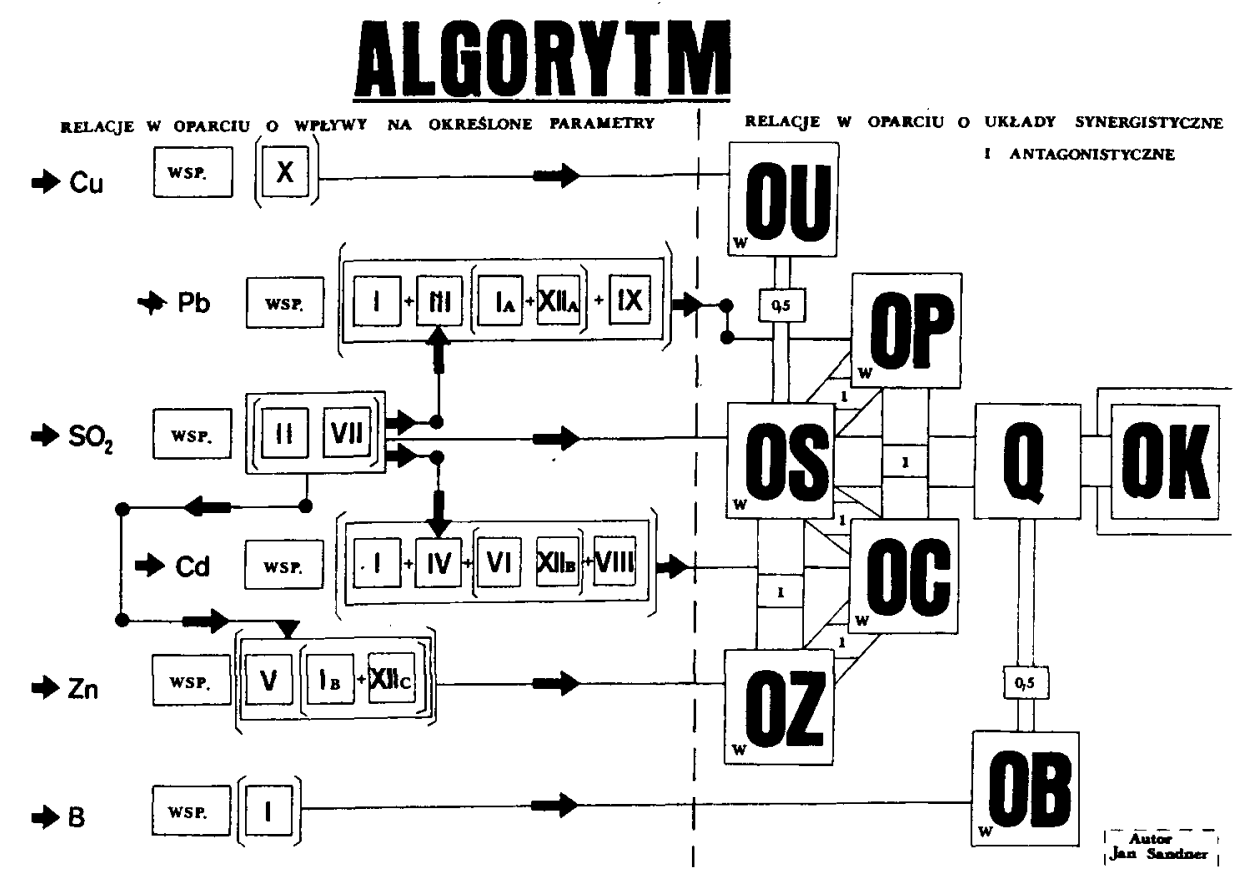

Bibliography

COLLIER B. D. i inni, 1978 - Ekologia Dynamiczna, PWRiL, Warszawa, s. 543.

CZARNOWSKA K., 1980 - Akumulacja metali ciężkich w glebach roślinach i niektórych zwierzętach na terenie Warszawy, Roczn. Glebozn., 31: s. 77-115.

BIERNACKA E., LIWSKI S., 1986 - Pierwiastki śladowe w' glebach wokót rafinerii ptockiej, Roczn. Glebozn., 37: s. 91-99.

KABATA-PENDIAS A., 1985 - Opad pierwiastków śladowych z atmosfery na powierzchnię gleb., Roczn.Glebozn., 36: s. 137-140.

KUCHARSKI R., Ocena obszarów wykorzystywanych rolniczo w aspekcie zanieczyszczenia środowiska, Inst. Kształ. Środow., Oddział Katowice, s. 51.

ODUM EUGENE P., 1982 - Podstawy ekologii, PWRiL, Warszawa, s. 661.

REMMERT H., 1985 - Ekologia, PWRiL, Warszawa, s. 403.

SANDNER J., 1989 - Model of valorization of soils under viewpoint of their potential resistance against some selected contaminants (Dissertation), SGGW-AR, Warszawa, s. 121. 
TROJAN P., 1981 - Ekologia ogólna, PWN, Warszawa, s. 418.

TURSKI R., BARAN S., 1978 - Metale ciężkie w glebach użyźnianych osadem ściekowym, Mat. I Kraj.Konf. Wpływ zanieczyszczeń pierwiastków śladowych na przyrodę i warunki rolnicze, Pulawy, s. 207-214.

WOJCIECHOWSKA-KAPUSTA A., TURSKI R., 1986 - Zawartośc zwiqzków' próchmicznych a rozpuszczalność niklu i otowiu, Roczn.Glebozn., 37: s. 351-362.

\section{Model waloryzacji gleb pod kątem ich potencjalnej odporności na zanieczyszczenia}

\section{STRESZCZENIE}

Postępujący proces industrializacji stanowi coraz większe zagrożenie dla środowiska przyrodniczego $w$ tym przede wszystkim dla użytków rolnych. Dla określenia równowagi tego środowiska niezbędne jest zbadanie wpływu tych zanieczyszczeń i określenie tzw. „potencjalnej odporności gleb na zanieczyszczenia".

Niniejsza praca próbuje rozwiązać problemy oceny wpływu, poprzez stworzenie tzw. algorytmu środowiskowego, w którym uwzględnione sa wszystkie podstawowe składowe środowiska glebowego, przy danej symulacji emisji zanieczyszczeń. Niezbędne obliczenia zostały wykonane przy zastosowaniu nowoczesnych technik obliczeniowych w Centrum Informatycznym SGGW-AR.

Zdefiniowanie tych zależności glebowych stanowi podstawę do konstruowania modeli, które obiektywnie będa określać faktyczny stan „odporności gleb na zanieczyszczenia". Modele te powinny stać się podstawą do planowania produkcji roślinnej dla obszarów o podwyższonym stopniu zagrożenia, a także wpłynąć na ciągle aktualny problem stereotypowego badania przydatności gleb do produkcji rolnej, znanego pod pojęciem "bonitacja gleb". 